\title{
Altered Slow Axonal Transport and Regeneration in a Myelin- Deficient Mutant Mouse: The Trembler as an in vivo Model for Schwann Cell-Axon Interactions
}

\author{
Sylvie de Waegh and Scott T. Brady \\ Department of Cell Biology, University of Texas Southwestern Medical Center, Dallas, Texas 75235
}

The thickness of the myelin sheath in normal myelinated nerve is proportional to the diameter of the axon. In the demyelinating mutant mouse, Trembler, not only is the thickness of the myelin sheath reduced, but the caliber of associated axons is smaller. This correlation suggests that the interaction between axons and Schwann cells may affect the shape and function of axons as well as properties of myelin. Since axonal diameter depends in part on the cytoskeleton and its movement with slow axonal transport, we have compared the properties of slow transport in the sciatic nerve of control and Trembler mice. Studies of the sciatic nerve of normal mice showed that the rates for proteins moving in slow component a (SCa) and slow component b (SCb) are similar to those previously measured in rat. In Trembler mice, tubulin was transported significantly faster than in control mice, with a rate of $1.73 \mathrm{~mm} / \mathrm{d}$ for Trembler compared to $1.56 \mathrm{~mm} / \mathrm{d}$ in the control. In contrast, the rate for neurofilament proteins was significantly slower in the Trembler (1.15 $\mathrm{mm} / \mathrm{d}$ compared to $1.38 \mathrm{~mm} / \mathrm{d}$ in the control). The majority of proteins in $\mathbf{S C b}$ were also transported slower in Trembler than control: actin and calmodulin were transported at $\mathbf{2 . 2 9}$ $\mathrm{mm} / \mathrm{d}$ as compared to $2.73 \mathrm{~mm} / \mathrm{d}$ in control, while spectrin and clathrin were transported at 2.01 and $2.43 \mathrm{~mm} / \mathrm{d}$, respectively, as compared to $2.54 \mathrm{~mm} / \mathrm{d}$ in control.

The importance of slow axonal transport in regeneration has been suggested by the clear correlation between the rates of regeneration and the rates of $\mathrm{SCb}$. Therefore, we evaluated regeneration of motor axons in Trembler mice to determine whether the regenerative response was affected by deficient Schwann cells. A slower regeneration rate was found in the Trembler $(1.7 \mathrm{~mm} / \mathrm{d})$ motor axon when compared to the control $(2.29 \mathrm{~mm} / \mathrm{d})$, but elongation of fibers in regeneration began after a shorter delay in the Trembler (1.6 d) than in control (2.5 d). Thus, deficient Schwann cells and poor myelination appear to affect both quantitative and qualitative properties of slow axonal transport. These changes lead to alterations in the morphological and physiological properties of affected axons.

Received Aug. 21, 1989; revised Dec. 26, 1989; accepted Dec. 27, 1989.

The studies described here were supported in part by grants from the NIH (NS23320 and NS23868). We would like to thank Martha Stokely and Enid Romanelli for their technical support.

Correspondence should be addressed to Dr. Scott Brady, Department of Cell Biology and Neuroscience, University of Texas Southwestern Medical Center, 5323 Harry Hines Boulevard, Dallas, TX 75235.

Copyright $\odot 1990$ Society for Neuroscience $0270-6474 / 90 / 061855-11 \$ 02.00 / 0$
Interactions between Schwann cells and axons play an important role in determining the morphology and physiological functions of a myclinatcd ncrve. Traditionally, these interactions were considered to be unidirectional: axons relayed information to the surrounding Schwann cells, which responded appropriately. This perception was based in large part on the assumption that axonal myelination was triggered by an increase in axonal diameter (Friede and Miyagishi, 1972). As a result, myelin sheath thickness and the internodal length were considered to be directly dependent on axonal caliber (Fraher, 1978). Axonal diameter was itself seen as being dependent on a variety of factors, including synthesis of proteins in the perikarya, availability of growth factors, and the neuron's developmental program, as well as factors that affect the density and distribution of microtubules and neurofilaments in the axon (Friede and Samorajski, 1970). By comparison, the glial cell was generally considered unimportant in the regulation of such neuronal parameters.

Recent observations suggest, however, that Schwann cells can and do modulate morphological properties of the axon. In primary cultures of peripheral nerve tissue, myelination of segments of axonal processes results in local increases in axonal caliber (Windebank et al., 1985; Pannese et al., 1988). Similarly, demyelination of the axon results in a reduction of axonal diameter in the demyelinated regions (Aguayo et al., 1977; Pollard and McLeod, 1980; Perkins et al., 1981) and changes in the organization of cytoskeletal elements (Hoffman et al., 1984; Parhad et al., 1987). As a result, it appears that the interactions between axons and Schwann cells are far more complex than originally believed.

Axonal diameter is not a predetermined neuronal parameter. Caliber changes during development and regeneration (Hoffman et al., 1985b); it also varies in certain neuropathies and after administration of a variety of drug agents causing giant axon neuropathies (Griffin et al., 1984; Monaco et al., 1985; Komiya et al., 1986). These changes are closely related to alterations in both the synthesis and axonal transport of the cytoskeletal proteins (Lasek et al., 1983; Wujek et al., 1986). For example, after axotomy, there is a decrease in neurofilament synthesis and axonal transport that correlates with a proportional decrease in axonal diameter (Hoffman et al., 1985a). Changes in the rates and composition of both slow component a ( $\mathrm{SCa}$ ) and slow component $b$ (SCb) have been noted during regeneration of fibers in the periphery (Oblinger and Lasek, 1988; Monaco et al., 1989). The close coupling of these events during development and regeneration suggests that other circumstances which result in reduced axonal caliber might well be associated with alterations in the synthesis and/or transport of the cytoskeleton. 

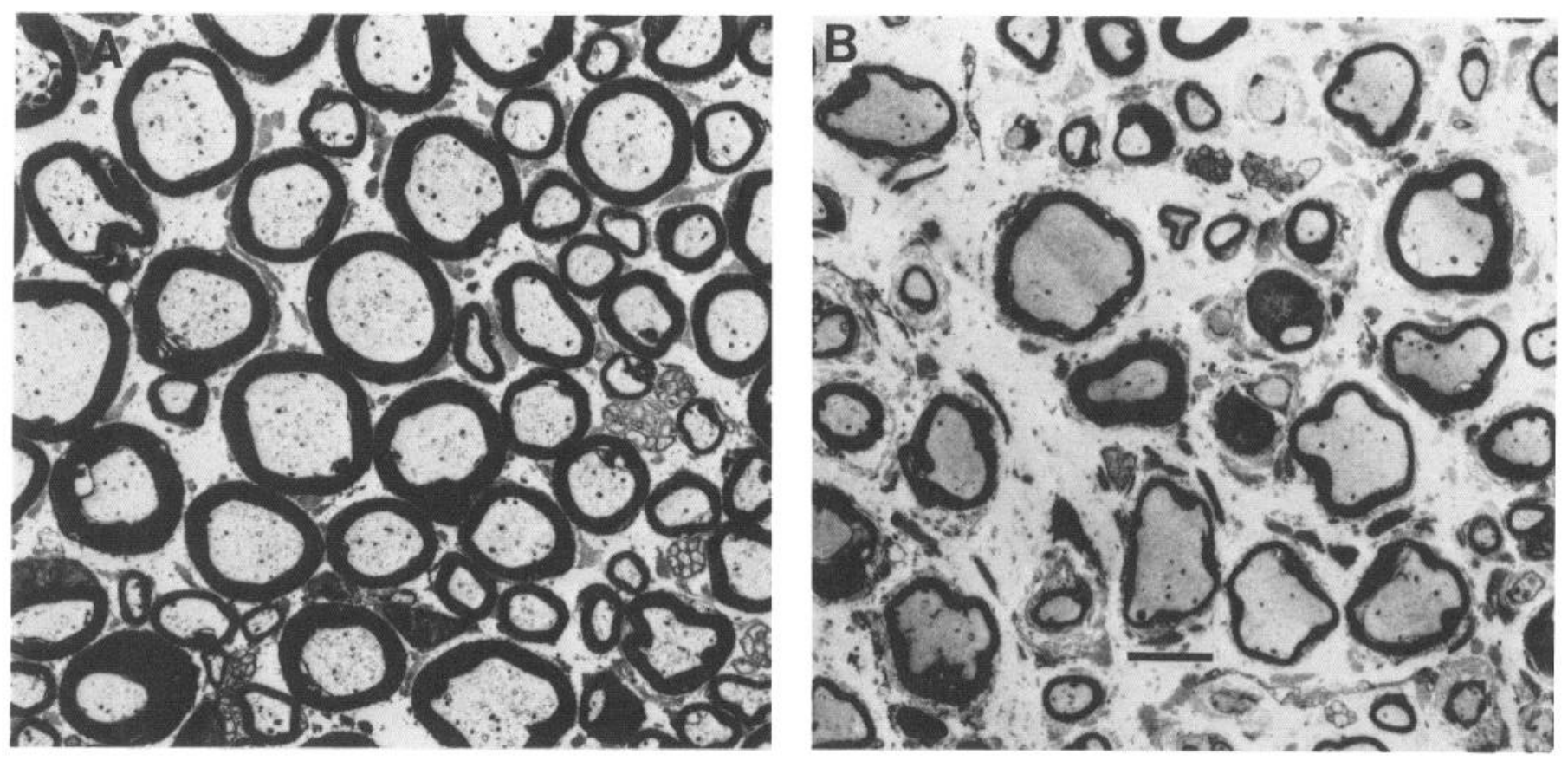

Figure 1. Electron micrographs of normal $(A)$ and Trembler $(B)$ sciatic nerve of 14-week-old mice. Scale bar, $5 \mu \mathrm{m}$.

To further characterize the roles played by Schwann cells and myelination on the physiological properties of the axon, particularly with respect to axonal diameter and the cytoskeleton, we have examined several relevant parameters in the Trembler mouse mutant. The Trembler mouse has a dominant mutation characterized by dysmyelination as well as demyelination in the PNS (Low, 1976a, b). Morphological analysis shows the presence of many unmyelinated large axons (Fig. 1), abnormal myelin with uncompacted sheaths, proliferation of connective tissue, and onion bulb neuropathy that increases with the age of the animal (Ayers and Anderson, 1975, 1976). In contrast, histological examination of the CNS reveals a normal or even slightly elevated level of myelination (Low, 1976a, b). Biochemical analysis indicates abnormalities in lipid composition and synthesis (Bourre et al., 1984; Heape et al., 1986; White et al., 1986). Initiation of myelination is delayed in the mutant and never attains completion. Interestingly, the average axonal diameter is reduced in peripheral nerves of Trembler mice.

\begin{tabular}{lcc}
\hline $\begin{array}{l}\text { Table 1. Comparison of the main morphological and physiological } \\
\text { characteristics of control and Trembler sciatic nerve }\end{array}$ & Control & Trembler \\
\hline $\begin{array}{l}\text { Mean axonal diameter of } \\
\text { myelinated mature fibers }\end{array}$ & $3-5 \mu \mathrm{m}$ & $2-3 \mu \mathrm{m}$ \\
$\begin{array}{l}\text { Unmyelinated axons }>1 \mu \mathrm{m} \\
\text { diameter }\end{array}$ & & \\
$\begin{array}{l}\text { Total number of axons } \\
\text { Number of Schwann cells }\end{array}$ & $924 \pm 17$ & $30-70 \%$ \\
$\begin{array}{l}\text { Number nerve cross-section } \\
\text { per nes } \\
\text { area }\end{array}$ & & $856 \pm 55$ \\
Conduction velocity $^{b}$ & $22 \pm 4$ & \\
\hline
\end{tabular}

${ }^{a}$ Low and McLeod, 1975.

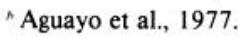

When a segment of sciatic nerve from Trembler mouse was grafted into a normal mouse and allowed to regenerate, the normal axons regrowing through the Trembler sections were locally reduced in diameter and exhibited the typical Trembler morphology (Aguayo et al., 1977). Similarly, Trembler axons regrowing through a graft of normal sciatic nerve became myelinated and their diameter increased in the region of the graft. Since the graft consists mainly of Schwann cells, Aguayo and his colleagues (1977) concluded that the disorder in the Trembler was localized to the Schwann cells. Neither the nature of the genetic defect in Trembler nor the molecular mechanisms underlying the demyelination and changes in axonal diameter have been elucidated.

The distinctive properties of the Trembler PNS are summarized in Table 1. These characteristic features of the mutant Trembler mouse, particularly the minimal or abnormal myelination and reduced axonal diameter, make it a very attractive model to define the mechanisms by which defective peripheral myelination can modify axonal properties. We have compared slow axonal transport and regeneration of peripheral axons in Trembler and normal mice. Both processes were altered by demyelination, suggesting that Schwann cells involved in myelination could affect axonal diameter by modifying the rate and the relative amount of cytoskeletal proteins transported along the axon.

\section{Materials and Methods}

Trembler mice C57BL/6 Tr and their normal C57BL/6N siblings were obtained from Jackson Laboratory (Bar Harbor, ME). For all these experiments, female mice 14-16 weeks old and weighing 18-22 gm were used. All animals were kept in a sterile environment and fed sterile food and water for the duration of the experiment. Radioactive $\mathrm{L}-\left({ }^{35} \mathrm{~S}\right)$-methionine (specific activity $800 \mathrm{mCi} / \mathrm{mol}$ ) and Fucose $\mathrm{L}-\left[5,6-{ }^{3} \mathrm{H}\right]$ (specific activity $48.4 \mathrm{Ci} / \mathrm{mmol}$ ) were obtained from Dupont NEN (Boston, MA).

Labeling of the slow axonal components. Slow axonal transport was studied in sensory fibers of the sciatic nerve by injection of ${ }^{35} \mathrm{~S}$-methionine in the dorsal root ganglia (DRG) of L5 on the right side. Mice 
were anesthetized by intramuscular injection of a mixture of $0.4-0.5$ $\mathrm{ml}$ of a $10 \%$ solution of xylazine (Rompun, $20 \mathrm{mg} / \mathrm{ml}$; Haver, Shawnee, $\mathrm{KS}$ ) and $0.3-0.4 \mathrm{ml}$ of a $50 \%$ solution of Ketamine (Vetalar, $100 \mathrm{mg} /$ $\mathrm{ml}$; Parke-Davis, Morris Plains, NJ). The L5 DRG was located by using appropriate anatomical landmarks, exposed by partial laminectomy, and injected with $0.4 \mathrm{mCi}{ }^{35} \mathrm{~S}$-methionine resuspended in one $\mu \mathrm{l}$ of distilled water. Mice were killed 4-14 d after injection. The right sciatic nerve was removed and frozen onto an index card with powdered dry ice. The frozen nerves were subsequently sectioned into consecutive 1.5 $\mathrm{mm}$ segments using a Mickel gel slicer. Segments were homogenized in $150 \mu \mathrm{l}$ of SUB $(0.5 \%$ SDS, $8 \mathrm{~m}$ urea, and $2 \% \beta$-mercaptoethanol) in a glass microhomogenizer. Homogenates were centrifuged at $10,000 \mathrm{rpm}$ in a Savant tabletop high-speed centrifuge for $10 \mathrm{~min}$. A $15 \mu \mathrm{l}$ aliquot was added to $5 \mathrm{ml}$ of Readysolve scintillation fluid from Beckman (Fullerton, CA) and the total radioactivity incorporated per segment was measured in a Beckman LS3801 liquid scintillation spectrometer. A $40-50 \%$ aliquot of each sample was analyzed by SDS-PAGE using a $4 \%$ stacking gel over a $6-17.5 \%$ gradient gel (Laemmli, 1970). Following electrophoresis, gels were stained in Serva blue, destained in methanol/ acetic acid, and processed for fluorography (Laskey and Mills, 1975). Gels were dried and exposed to X-ray film at $-80^{\circ} \mathrm{C}$ for 3-14 d.

Fluorographs were used to localize 8 marker proteins of slow axonal transport for SCa (neurofilament triplet, tubulin) and $\mathrm{SCb}$ (clathrin, spectrin, calmodulin, and actin). Bands containing these proteins were cut out of the gel and solubilized at $60^{\circ} \mathrm{C}$ in $0.75 \mathrm{ml}$ of $30 \%$ peroxide for $2 \mathrm{~d}$. Five milliliters of Readysolve were added to each vial and the radioactivity incorporated in each protein per segment was measured. We then plotted the profile of radioactivity along the nerve for each marker protein to determine a peak of activity along the nerve. The velocity of each protein was calculated by measuring the slope of the linear regression function for distance from the DRG of the radioactivity peak at various times after injection. The statistical significance of differences in the slow axonal transport between Trembler and control mice was determined by Student's $t$ test. Velocities were calculated for each time point and each animal separately. Based on these measurements, we determined the average velocity as well as standard deviation for the populations of measured velocities for control and for Trembler. The average velocities measured by this manner were comparable to the velocities obtained by using the slope of the linear regression as described above. The value $t$ was calculated based on a comparison of these 2 sets of velocities.

Electron microscopy. Sciatic nerves were removed from mice immediately after death, cut in $1-\mathrm{mm}$ segments, and fixed for $2 \mathrm{hr}$ in $2 \%$ glutaraldehyde and $2 \%$ formaldehyde in cacodylate buffer. After $1 \mathrm{~h}$ postfixation in $1 \%$ osmium tetroxide, nerve segments were dehydrated in a graded series of ethanol and embedded in Epon-Araldyte resin. Ultrathin sections were stained with uranyl acetate and lead citrate.

Analysis of regeneration for motor neuron axons in the sciatic nerve. Regeneration of axons from motor neurons of the mouse sciatic nerve was measured by incorporation of ${ }^{3} \mathrm{H}$-fucose at the terminal of the growing tips. Six mice were used for each time point. At day 1, mice were anesthetized and the right sciatic nerve was crushed $10 \mathrm{~mm}$ away from the spinal cord with \#5 Dumont forceps 2 times for $20 \mathrm{sec}$ each time. At 2-8 d after the crush, mice were reanesthetized and injected with $50 \mu \mathrm{Ci}$ of ${ }^{3} \mathrm{H}$-fucose distributed in 3 injections of $0.5 \mu$ lin the ventral horn between T13 and L1. T13 was located by noting the level for attachment of the last rib. Twenty-four hours after injection, mice were killed and both sciatic nerves were removed and sectioned into $1.5 \mathrm{~mm}$ segments. All segments from the crushed nerve and one segment from the control side were homogenized in $100 \mu \mathrm{l}$ of SUB. Aliquots of $65 \mu \mathrm{l}$ each were mixed with $5 \mathrm{ml}$ Readysolve and the amount of label per segment determined by liquid scintillation spectrometry. The DPM of ${ }^{3} \mathrm{H}$-fucose per segment was plotted as a function of distance from the crush. The velocity of regenerating fibers was measured by plotting the distance of the peak of radioactivity from the crush as a function of days after crush.

\section{Results}

The fundamental properties of slow axonal transport have been well conserved among the various species examined (Hoffman and Lasek, 1975; Garner and Lasek, 1981, 1982; Brady, 1985), but rates of transport for the different components may vary between species or even between different nerves in an animal
Table 2. Comparison of velocities for slow axonal transport for $\mathrm{SCb}$ and SCa proteins in sciatic nerve of control and Trembler mice

\begin{tabular}{lll} 
& Control & Trembler \\
\hline SCh & & \\
$\quad$ Actin & $2.73 \pm 0.32$ & $2.29 \pm 0.18^{a}$ \\
Calmodulin & $2.73 \pm 0.32$ & $2.29 \pm 0.18^{a}$ \\
Spectrin & $2.54 \pm 0.40$ & $2.01 \pm 0.15^{a}$ \\
Clathrin & $2.54 \pm 0.40$ & $2.43 \pm 0.22$ \\
SCa & & \\
$\quad$ Neurofilament & $1.38 \pm 0.12$ & $1.15 \pm 0.14^{a}$ \\
Tubulin & $1.56 \pm 0.13$ & $1.73 \pm 0.18^{\prime \prime}$
\end{tabular}

Rates are significantly different between control and Trembler. Velocities were not significantly different for clathrin. The velocities for $\mathrm{SCb}$ were obtained by measuring the rate of transport in 8 controls and 8 Trembler mice. The velocities for SCa were obtained using 14 controls and 12 Trembler mice.

"Rate significantly different at $p<0.01$

${ }^{\text {h }}$ Rate significantly different at $p<0.05$.

(Lasek et al., 1984; McQuarrie et al., 1986; Oblinger et al., 1987). Therefore, the first step in this study was to characterize slow axonal transport in sensory fibers of the $\mathrm{C} 57 \mathrm{Bl} / 6 \mathrm{~N}$ mouse. Using this information as a basis for comparison, suitable quantitative analyses could be made of the differences between $\mathrm{C} 57 \mathrm{Bl}$ and Trembler mice. Characterization of the slow component of axonal transport in the normal mouse sciatic nerve showed that the rates of transport of the major $\mathrm{SCa}$ and $\mathrm{SCb}$ proteins in the PNS of the mouse were within the range of rates previously measured in the peripheral nerves of other rodents.

For evaluation of SCa, animals were killed 7-14 d after injection of ${ }^{35} \mathrm{~S}$-methionine in the DRG of L5. Neurofilament proteins and tubulin werc uscd as markcrs for determining transport rates in SCa. Analysis of neurofilament triplet transport indicated that the peak of radioactivity was moving at a rate of $1.38 \pm 0.12 \mathrm{~mm} / \mathrm{d}$. The peak of tubulin was moving at $1.56 \pm$ $0.13 \mathrm{~mm} / \mathrm{d}$ in the sensory axons of the sciatic nerve. As is usually observed in the PNS, tubulin was moving at 2 different rates (Black and Lasek, 1980; Brady and Lasek, 1982; Lasek and Brady, 1982; Tashiro el al., 1984). The majority of the tubulin moved with $\mathrm{SCa}$, but a significant fraction was moving with the leading front at $\mathrm{SCb}$ rates, similar to rates seen for the actin peak. This fast-moving fraction of tubulin is the reason that average tubulin axonal transport rates are higher than neurofilament rates in peripheral nerves. Measurement of the velocity of SCb was based on positions of 4 different proteins. For actin and calmodulin, the peak of radioactivity was moving at 2.73 $\pm 0.32 \mathrm{~mm} / \mathrm{d}$, while clathrin and brain spectrin moved at 2.54 $\pm 0.40 \mathrm{~mm} / \mathrm{d}$. The rates of transport for the different proteins of SCa and SCb are summarized in Table 2.

To determine the effects of poor myelination on the properties of slow axonal transport, we compared both qualitative and quantitative aspects of slow axonal transport in Trembler mutants with those in normal C57BL/6N mice. Since the primary difference between Trembler and normal mice is that Trembler axons are poorly myelinated, presumably any differences observed can be related to the defective interactions between Schwann cell and axon. In order to understand the significance of any differences in slow axonal transport observed between the normal and the Trembler mouse, one must keep in mind that the average axonal diameter is smaller in Trembler (Fig. 1; Table 1). The organization and transport of the axonal cyto- 


\section{CONTROL $10 \mathrm{~d}$}

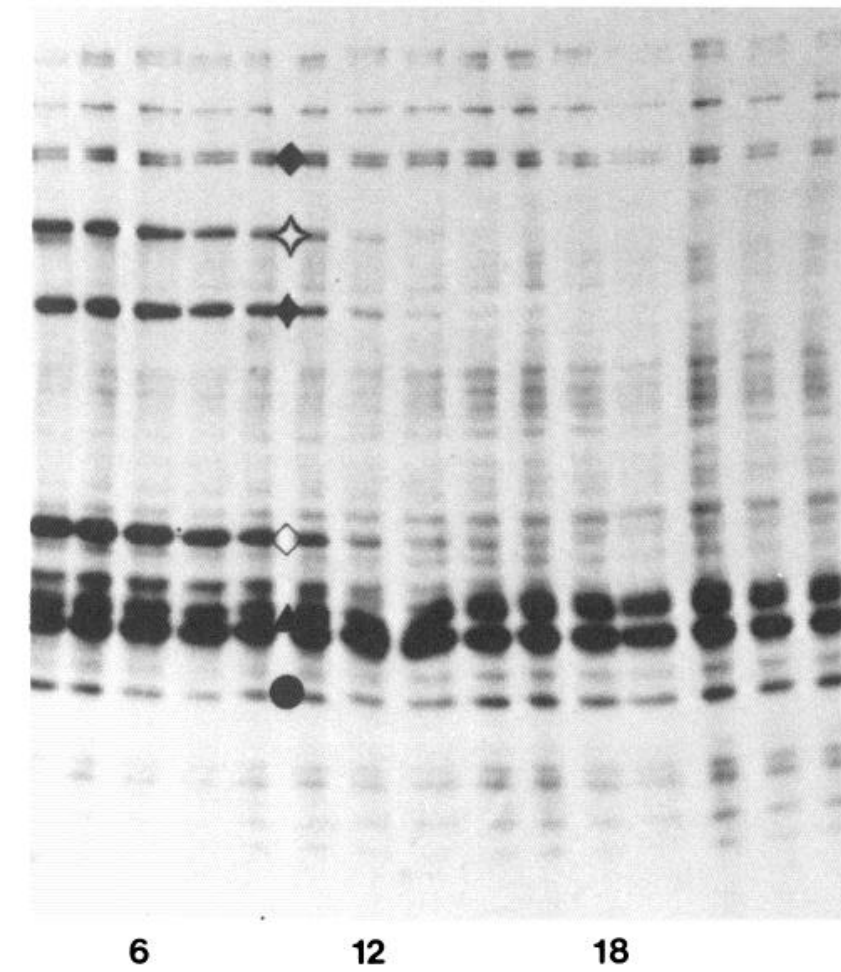

TREMBLER $10 \mathrm{~d}$

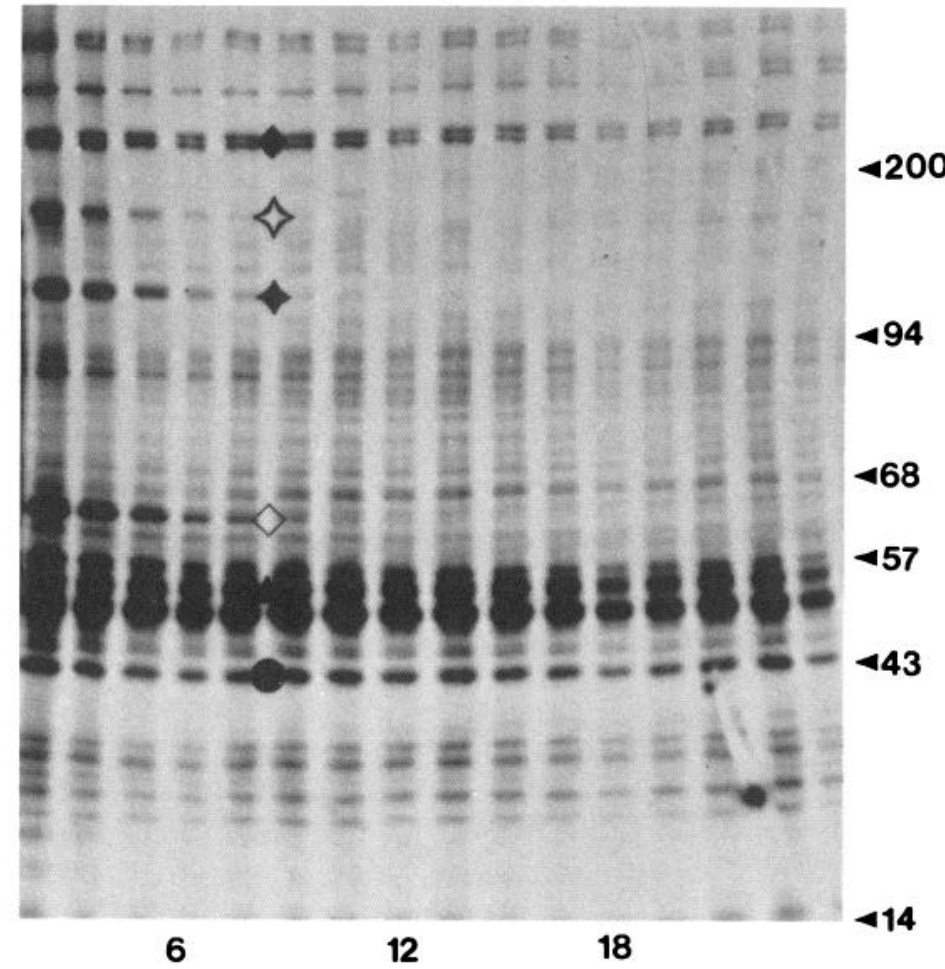

Figure 2. SDS-PAGE fluorographs showing labeled polypeptides in consecutive $1.5-\mathrm{mm}$ segments of the right sciatic nerve of control and Trembler mice $10 \mathrm{~d}$ after injection of $0.4 \mathrm{mCi}{ }^{35} \mathrm{~S}$-methionine into the DRG of L5. Fluorographs were exposed for $9 \mathrm{~d}$. The polypeptides are indicated by symbols: brain spectrin $(\diamond)$, neurofilament high $M_{\mathrm{r}}$ subunit (NFH) $(\diamond)$, medium $M_{\mathrm{r}}$ subunit (NFM) $(\diamond)$, and low $M_{\mathrm{r}}$ subunit $(\mathrm{NFL})(\diamond)$, tubulin $(\boldsymbol{\Delta})$, and actin (๑). The numbers on the bottom represent the distance from the dorsal root ganglion in millimeters. The positions of molecular weight markers are indicated on the right. These fluorographs show clearly that neurofilament proteins are moving slower in the Trembler than in the control.

skeleton are well correlated with axonal caliber (Hoffman and Lasek, 1980; Willard and Simon, 1983; Wujek and Lasek, 1983; Hoffman el al., 1984). Thus, differences in transport would be expected, since the major components of slow axonal transport are elements of the cytoskeleton (Hoffman and Lasek, 1975), including microtubules and neurofilaments. We were interested in determining the extent to which slow axonal transport of the cytoskeleton was altered in the reduced caliber axons surrounded by myelination-deficient Trembler Schwann cells.

The first approach taken represented a qualitative analysis, comparing the distribution of marker proteins at different intervals in fluorographs for normal and Trembler mice. Comparison of the fluorographs of transported proteins labeled 10 $\mathrm{d}$ after injection of ${ }^{35} \mathrm{~S}$-methionine indicated that several qualitative differences existed between normal and Trembler mice (Fig. 2). For example, the relative amount of tubulin, as measured by the ratio of labeled tubulin to labeled actin, is greater in the Trembler than in the normal mouse. When the fluorographs of transported proteins in Trembler mice are compared to those of controls, a greater proportion of this tubulin is carried with $\mathrm{SCb}$ in the mutant. Quantitation of these increases indicated that there was a $40 \%$ increase in the relative amount of labeled tubulin as measured by the ratio of labeled $\mathrm{SCb}$ tubulin to labeled actin (Fig. 3). This increase in the percentage of labeled tubulin is not an absolute value, but reflects a relative increase when compared to other $\mathrm{SCb}$ proteins. For each nerve segment, 8 proteins were isolated and their radioactivity incorporation was measured. The total radioactivity present in these 8 markers was standardized to $100 \%$ to facilitate comparison between Trembler and control nerves. The values in Figure 3 represent the relative percentages of selected proteins compared to the total of these 8 marker proteins. To show that the relative increase in labeled tubulin was not due to a decrease in other $\mathrm{SCb}$ proteins (calmodulin, spectrin, clathrin), we calculated the ratio between the percentage of tubulin and percentage of actin, another $\mathrm{SCb}$ protein that did not seem to decrease in the Trembler. As shown in Figure 3, only tubulin levels were significantly different between Trembler and control, suggesting a relative increase in $\mathrm{SCb}$ tubulin in the Trembler.

A different pattern was noted for spectrin, another cytoskeleton-associated protein transported as part of both $\mathrm{SCa}$ and $\mathrm{SCb}$ (Levine and Willard, 1981). Examination of a number of fluorographs suggested that the spectrin band in SCa is more heavily labeled in the Trembler than in the control. Preliminary results based on quantitative comparison of a series of fluorographs suggest that the amount of SCa spectrin present in the Trembler is increased as much as 2-fold when compared to the control. Further analyses are needed to ascertain the specific changes in spectrin transport. Although we chose to focus here on a few identified proteins whose transport properties were well characterized, it should be emphasized that these comments do not exclude the possibility that other $\mathrm{SCa}$ or $\mathrm{SCb}$ proteins might also be affected in the Trembler.

Finally, Figure 2 illustrates that the rate of axonal transport 


\section{$\%$ of $\mathrm{SCb}$ and $\mathrm{SCa}$ Proteins}

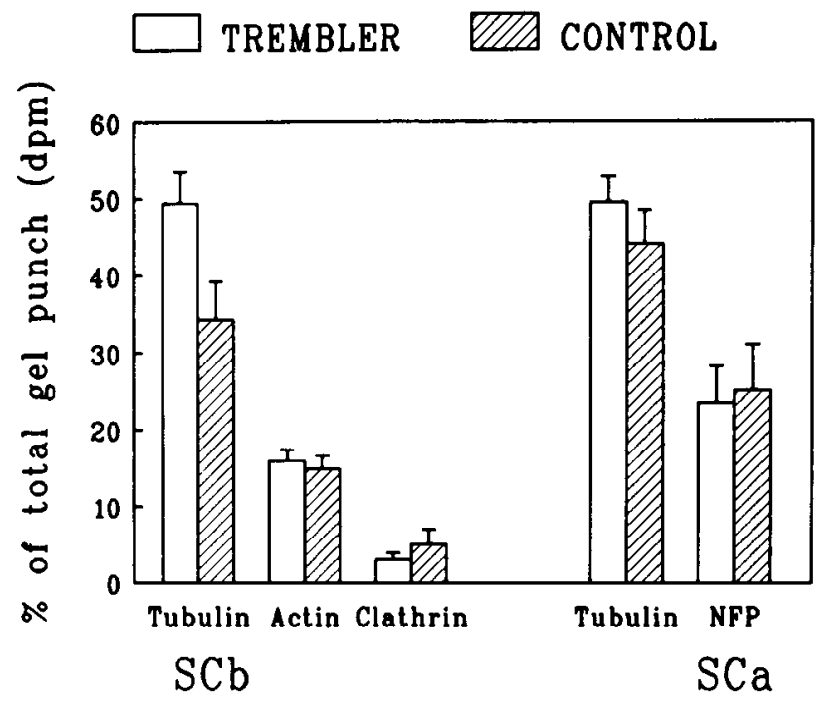

Figure 3. Quantitation of radioactivity associated with 3 of the major $\mathrm{SCb}$ and $2 \mathrm{SCa}$ proteins in control and Trembler mice. For each segment, 8 proteins were cut out of the gels, solubilized, and their radioactivity determined. The total radioactivity from all bands excised from the gel was standardized to $100 \%$ to facilitate comparison between Trembler and control nerve. The values represent the relative percentage of selected proteins compared to the total of these 8 markers. Data for neurofilament proteins represents the combined total of all 3 subunits. In the Trembler, there is a $40 \%$ increase in the relative amount of SCb tubulin measured by the ratio between the percentage of tubulin and the percentage of actin, another $\mathrm{SCb}$ protein that did not seem to change in the Trembler.

for neurofilament proteins was slower in the myelin-deficient mutant. Several lines of evidence indicate that the decrease in neurofilament labeling in Trembler was not due to a reduction in the total amount of neurofilament present in Trembler axons. First, quantitative immunoblots with a number of antibodies to neurofilaments (data not shown) indicate that similar amounts of neurofilament protein are present in control and Trembler nerves. Second, a variety of exposures have been used for different experiments in order to reveal even the small amounts of neurofilament protein transported in the nerve. Although other Trembler proteins show density of exposure as great as or greater than in control, no labeled neurofilament protein was detected in more distal segments. Third, we are concerned with the movement of the peak of neurofilament proteins, representing the movements of the bulk of the neurofilament protein. Finally, conclusions about rate of neurofilament transport were based on quantitative analyses as described below.

Our second approach consisted of a quantitative analysis of differences between the normal and the Trembler mouse in axonal transport velocities for the various marker proteins. Several significant differences were noted in SCa. The SCa peak of radioactivity for tubulin in Trembler nerves was moving at a rate of $1.73 \pm 0.18 \mathrm{~mm} / \mathrm{d}$ compared to $1.56 \pm 0.13 \mathrm{~mm} / \mathrm{d}$ in the control (Fig. 4). Statistical analysis using Student's $t$ test showed that these 2 rates were significantly different at $p<0.05$. The apparent increase in rate of transport for tubulin in the Trembler is probably due to the apparent displacement of the tubulin peak resulting from an increase in the amount of tubulin transported as part of $\mathrm{SCb}$, as noted above. By contrast, the

\section{SLOW AXONAL TRANSPORT OF TUBULIN}

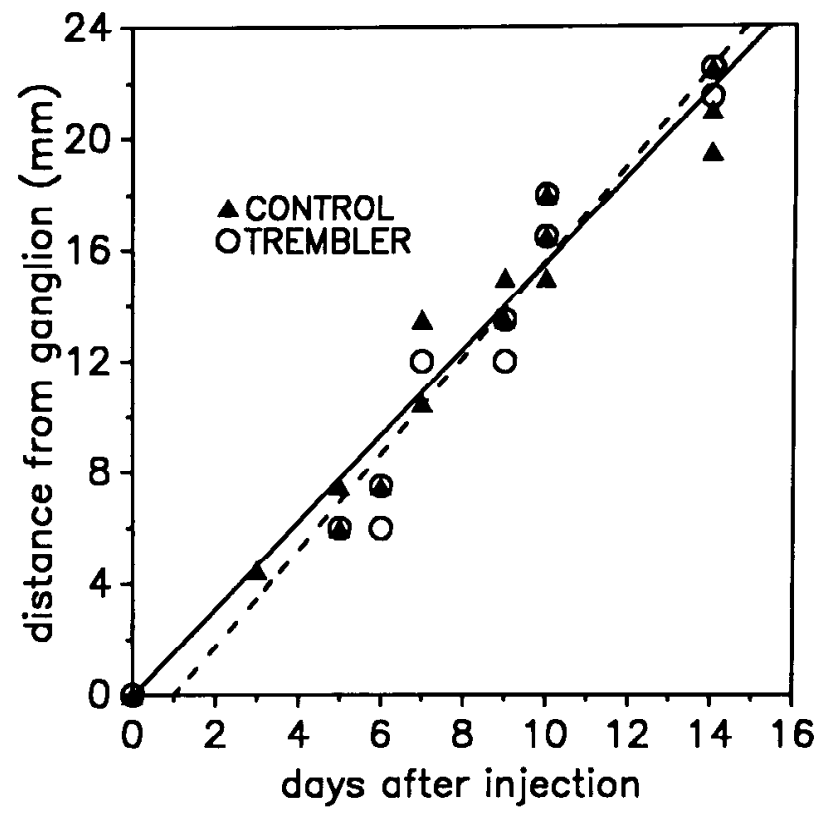

Figure 4. Position of labeled SCa tubulin peaks in sciatic nerve of 14 control and 12 Trembler mice 3-14 d after microinjection of $0.4 \mathrm{mCi}$ ${ }^{35} \mathrm{~S}$-methionine in the DRG of L5. The distance of the peak of radioactivity from the DRG is proportional to the time after injection. A line has been fitted to the data using a linear regression $(r=0.97$ for control, $r-0.96$ for Trembler). The slope of the line fitted in this manncr is a measure of the velocity of transport for tubulin (control $=1.56$ $\mathrm{mm} / \mathrm{d}$, Trembler $=1.73 \mathrm{~mm} / \mathrm{d}$ ). Although plots are similar, the slopes of the lines, representing velocity, are significantly different at $p<0.05$.

neurofilament peak in the Trembler was slowed, moving at 1.15 $\pm 0.14 \mathrm{~mm} / \mathrm{d}$ in the Trembler (Fig. 5). This rate was significantly slower (with a $p<0.01$ ) than the rate of movement of neurofilament in the control $(1.38 \pm 0.12 \mathrm{~mm} / \mathrm{d})$.

Differences in the transport of $\mathrm{SCb}$ proteins were also seen. There was a general tendency toward slowing of the $\mathrm{SCb}$ proteins in the Trembler. The polypeptide composition of $\mathrm{SCb}$ is much more complex than that of $\mathrm{SCa}$, so we restricted analysis to a few marker proteins found to be representative of $\mathrm{SCb}$ in prior studies. In control mouse, the majority of the $\mathrm{SCb}$ proteins were found to be transported at approximately the same velocity. In the Trembler mouse, however, there was more variability in the velocities of transport for the different marker proteins of $\mathrm{SCb}$. The pcaks of actin and calmodulin were moving at $2.29 \pm 0.18$ $\mathrm{mm} / \mathrm{d}$, which is significantly slower (with a $p<0.01$ ) than the rates of transport for these same proteins in the control mice $(2.73 \pm 0.32 \mathrm{~mm} / \mathrm{d})$ (Fig. 6). On the other hand, spectrin and clathrin were found to move at different rates in the Trembler. The clathrin peak was the fastest moving of the $\mathrm{SCb}$ marker proteins in Trembler, with a velocity of $2.43 \pm 0.22 \mathrm{~mm} / \mathrm{d}$. This rate was not significantly different from the rate of transport for clathrin in the control nerve $(2.54 \pm 0.40 \mathrm{~mm} / \mathrm{d})$ (Fig. 7). By contrast, SCb spectrin moved even slower than actin or calmodulin in Trembler (with a peak velocity of $2.01 \pm 0.15$ $\mathrm{mm} / \mathrm{d}$ ) as compared to the rate of $2.54 \pm 0.40 \mathrm{~mm} / \mathrm{d}$ for $\mathrm{SCb}$ spectrin in the control nerve (Fig. 7). This difference in spectrin transport between Trembler and control was significant at $p<$ 0.01 .

The rate of regeneration for axons is another process depen- 


\section{SLOW AXONAL TRANSPORT OF NEUROFILAMENTS}

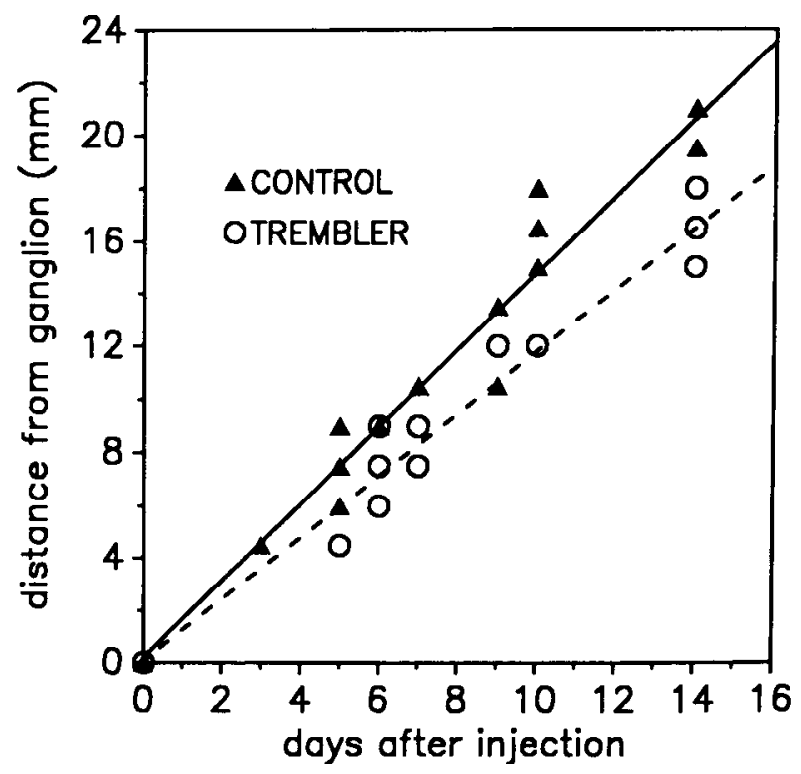

Figure 5. Position of labeled SCa neurofilament peaks in sciatic nerve of 14 control and 12 Trembler mice as in Figure 4. The correlation coefficients for the line are: $r=0.96$ for control, $r=0.97$ for Trembler, giving estimated rates for neurofilament proteins of $1.38 \mathrm{~mm} / \mathrm{d}$ for control and $1.15 \mathrm{~mm} / \mathrm{d}$ for Trembler. There is a significant difference $(p<0.01)$ between the velocity of neurofilament transport in the Trembler and in the control.

dent on the dynamics of the axonal cytoskeleton (Wujek and Lasek, 1983; Hoffman et al., 1985a, b). Regeneration of peripheral nerves in rodents has been extensively described, but the factors that determine the efficacy of regeneration are incompletely understood. One factor that has been well established is the importance of the glial environment for the growing neurite (Lasek et al., 1981), i.e., the Schwann cells in the periphery (Aguayo et al., 1981; Benley and Aguayo, 1982). Lasek and others (Hoffman and Lasek, 1980; Wujek and Lasek, 1983) have shown that regeneration rates are correlated with slow axonal transport, so differences in slow axonal transport might alter regeneration. After measuring different velocities of axonal transport between normal and Trembler, we compared the regeneration rates for myelin-deficient fibers and control fibers.

Table 3. Comparison of rates of regeneration in 21 control and 21 Trembler sciatic motor axons

\begin{tabular}{lcclll} 
& \multicolumn{2}{l}{$\begin{array}{l}\text { Regeneration rates } \\
\text { (mm/day) }\end{array}$} & & \multicolumn{2}{l}{$\begin{array}{l}\text { Delay before } \\
\text { regeneration } \\
\text { (days) }\end{array}$} \\
\cline { 2 - 3 } \cline { 5 - 6 } \cline { 5 - 6 } Control & Front & Peak & & Front & Peak \\
\hline Trembler & 2.53 & 2.29 & & 1.22 & 2.49 \\
& \pm 0.20 & \pm 0.20 & & \\
\% difference & 2.16 & 1.71 & & 0.70 & 1.63 \\
& \pm 0.20 & \pm 0.17 & & & \\
\hline
\end{tabular}

Rates are measured by injection of ${ }^{3} \mathrm{H}$-fucose in the spinal cord.

Significantly different at $p<0.01$.

\section{SLOW AXONAL TRANSPORT ACTIN/CALMODULIN}

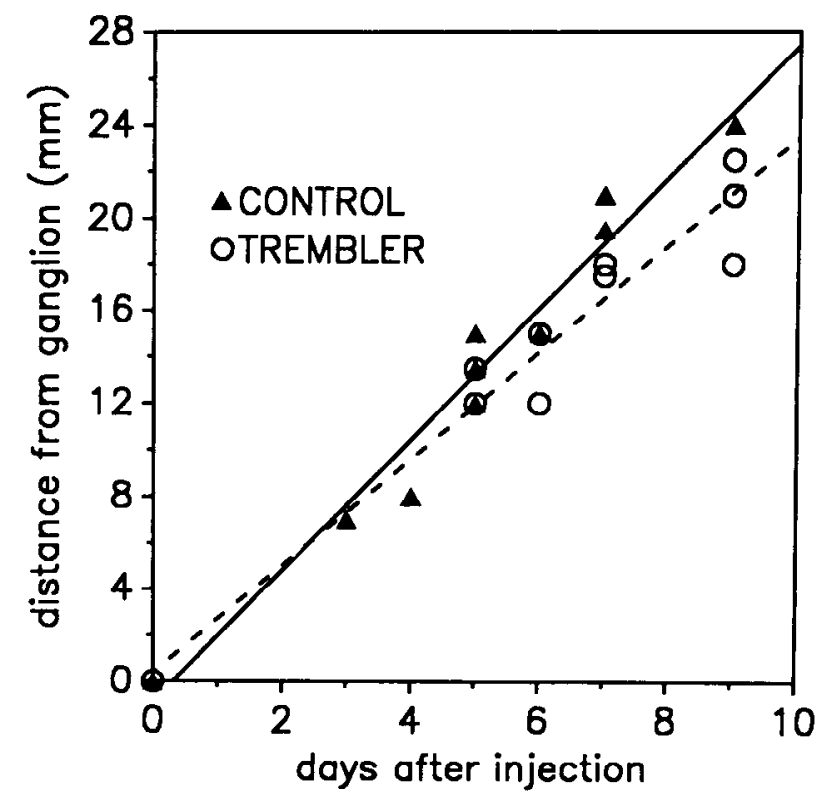

Figure 6. Position of labeled SCb actin and calmodulin peaks in sciatic nerve of 8 control and 8 Trembler mice 3-9 $\mathrm{d}$ after microinjection of $0.4 \mathrm{mCi}^{35} \mathrm{~S}$-methionine in the DRG of L5. The correlation coefficients for the line are: $r=0.95$ for control, $r=0.97$ for Trembler, giving estimated rates for actin and calmodulin of $2.73 \mathrm{~mm} / \mathrm{d}$ for control and $2.29 \mathrm{~mm} / \mathrm{d}$ for Trembler. Slow axonal transport of actin and calmodulin is significantly slower in the Trembler when compared to the control.

The regrowth of axons was measured for both the peak (averagegrowing fibers) and the front (fastest-growing fibers) of the regenerating nerve. Motor fibers were chosen for evaluation in the regeneration studies, because they represent a more homogeneous population of fibers that regenerate in a more coherent fashion than the sensory fibers of the sciatic nerve.

In the control nerves, the majority of the fibers regenerated at a rate of $2.29 \pm 0.20 \mathrm{~mm} / \mathrm{d}$ after an average delay of $2.49 \mathrm{~d}$ before the beginning of elongation (Fig. $8 \mathrm{~A}$ ). The fastest-moving fibers were regrowing at $2.53 \pm 0.2 \mathrm{~mm} / \mathrm{d}$ after a delay of only $1.22 \mathrm{~d}$ (Fig. $8 B$ ). In contrast, the fibers in Trembler regrew at a slower rate, but after a shorter delay. The majority of the Trembler fibers regenerated at a rate of $1.70 \pm 1.17 \mathrm{~mm} / \mathrm{d}$ after a delay of only $1.63 \mathrm{~d}$. The fastest-growing fibers in Trembler started regrowth only $0.7 \mathrm{~d}$ after the crush, but elongated at a rate of $2.16 \pm 0.25 \mathrm{~mm} / \mathrm{d}$. Regeneration rates and delay are summarized in Table 3 . Initiation of regeneration in the Trembler apparently occurs almost immediately after sciatic nerve crush, as if the nerve was in a regeneration ready state.

\section{Discussion}

Contact between the 2 major cell types of peripheral nerve, Schwann cells and neurons, extends over an unusually large surface area. Such extensive contacts between 2 cell types might be expected to play an important physiological role in modulating the properties of both cell types. Functionally, however, very little is known about the nature and function of any information transferred between axon and Schwann cells. Historically, the primary type of interaction between these 2 cell types was thought to be the unidirectional influence of the axon on surrounding Schwann cells. During myelination, the increase 


\section{SLOW AXONAL TRANSPORT CLATHRIN/SPECTRIN}

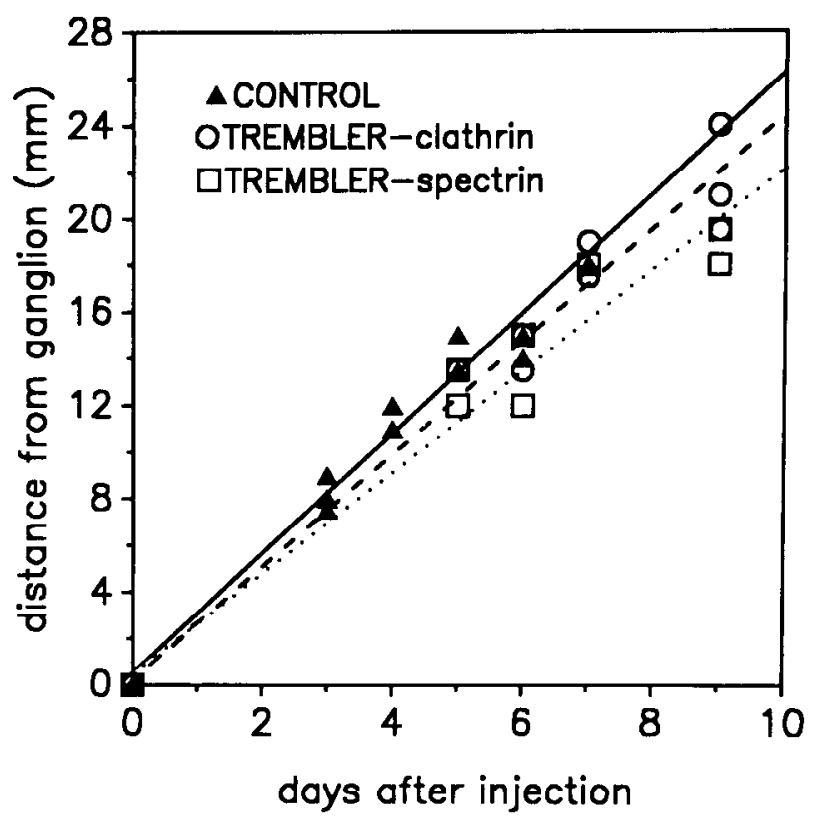

Figure 7. Position of labeled $\mathrm{SCb}$ clathrin and spectrin peaks in sciatic nerve of 8 control and 8 Trembler as in Figure 6 . The correlation coefficients are: $r=0.92$ for control, $r=0.98$ for Trembler clathrin, and $r=0.95$ for Trembler brain spectrin, giving estimated rates for clathrin and spectrin of $2.54 \mathrm{~mm} / \mathrm{d}$ for control, $2.01 \mathrm{~mm} / \mathrm{d}$ for Trembler spectrin, and $2.43 \mathrm{~mm} / \mathrm{d}$ for Trembler clathrin. There is a significant difference in the slow axonal transport for spectrin between the Trembler and the control but not for clathrin.

in axonal diameter that occurs as the neuron matures seems to trigger myelin production by the Schwann cell. The larger the axonal caliber, the thicker the myelin sheath becomes. Schwann cell behavior during myelination was thought to depend directly on the morphology and influence of the axon, with very little left to be determined by the Schwann cell itself. Although this perception is changing, even now the Schwann cell is often regarded as a passive structural cell, rather than as an active partner in a dialogue between the 2 cell types.

Evidence has now accumulated that Schwann cells can also modify axonal properties. One example is found in the work of Aguayo and his associates on the myelin-deficient Trembler mouse (Aguayo et al., 1977). In this mouse mutant, defective Schwann cells are unable to myelinate large axons effectively (see Table 1 and Fig. 1). As a result, when a piece of sciatic nerve from a myelin-deficient Trembler mouse was grafted into a normal mouse nerve, the grafted region contained little or no myelin. In the same nerve, both proximal and distal regions of the nerve with normal Schwann cells have myelin sheaths and calibers indistinguishable from control nerves. Somewhat surprisingly, however, the diameter of the regrowing normal axons was reduced in those regions surrounded by the grafted Trembler Schwann cells.

Additional evidence of Schwann cell influence on axons was obtained from in vitro experiments by Windebank et al. (1985). The diameter of axonal processes on cultured neurons is modified by the presence of Schwann cells; i.e., the initiation of myelination by a Schwann cell will produce a local enlargement

\section{regeneration in mouse sciatic nerve velocity of the front}

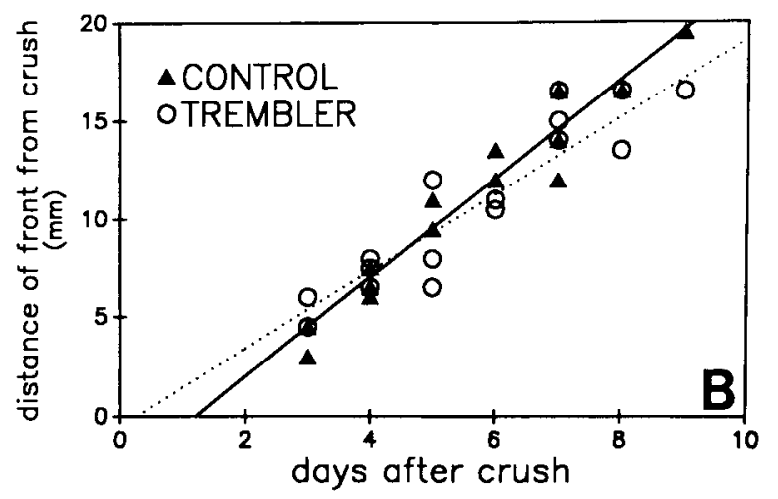

\section{regeneration in mouse sciatic nerve velocity of the peak}

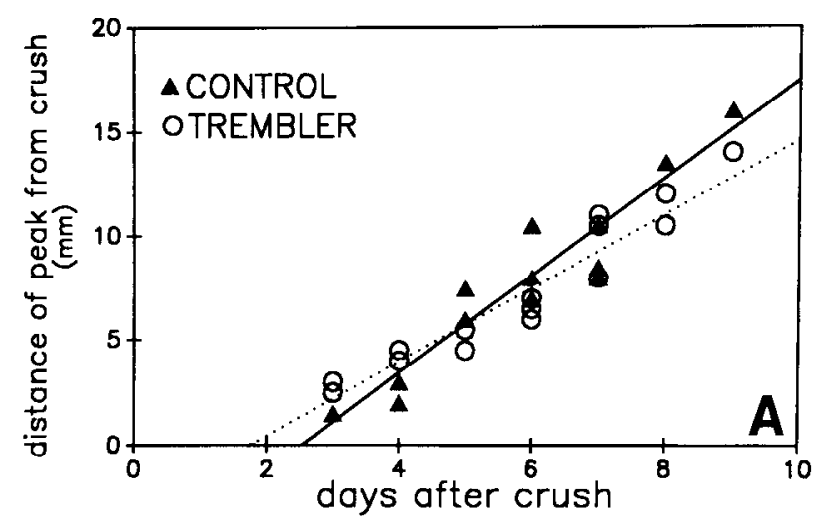

Figure 8. Velocity of regeneration of motor sciatic nerve in 21 control and 21 Trembler mice. Position of labeled growing axons peaks $(A)$ and fronts $(B) 3-9 \mathrm{~d}$ after a crush $10 \mathrm{~mm}$ away from the spinal cord and 24 $\mathrm{hr}$ after microinjection of the ventral horn of T13-Ll with $50 \mu \mathrm{Ci}$ of ${ }^{3} \mathrm{H}$-fucose. The rates of regeneration measured by the slope of the fitted line are, in control: $2.53 \mathrm{~mm} / \mathrm{d}$ for the front and $2.29 \mathrm{~mm} / \mathrm{d}$ for the peak; in Trembler: $2.16 \mathrm{~mm} / \mathrm{d}$ in the front and $1.71 \mathrm{~mm} / \mathrm{d}$ in the peak. The delay before regeneration was estimated by the intersection between the fitted line and the $\mathrm{X}$-axis. The delays measured are in control: 1.22 $\mathrm{d}$ for the front and $2.49 \mathrm{~d}$ for the peak; in Trembler: $0.7 \mathrm{~d}$ for the front and $1.63 \mathrm{~d}$ for the peak. Regeneration of sciatic nerve in Trembler mouse starts after a shorter delay than in the control but proceeds at a slower rate.

in axonal diameter which is apparent when compared to adjacent regions with nonmyelinating Schwann cells surrounding the same axon (Pannese et al., 1988). Finally, Parhad et al. (1987) have reported changes in the organization of axonal neurofilaments in demyelinated segments following treatments that produce focal demyelination. All of these observations strongly suggest that some influence of the myelinating Schwann cell acts locally on regions of the axon in direct contact with the Schwann cell.

Correlations between changes in axonal caliber and changes in the axonal cytoskeleton in a variety of circumstances have demonstrated the importance of the cytoskeleton in determining axonal caliber. Cytoskeletal elements are carried by slow axonal transport, which can be divided into 2 major rate groups: SCa 
and SCb (Hoffman and Lasek, 1975; Brady and Lasek, 1982; Lasek and Brady, 1982; Lasek et al., 1984). SCa, the slowest of the 2 rate components, consists predominantly of tubulin and neurofilament triplet proteins conveyed down the axon at rates ranging from about $0.1 \mathrm{~mm} / \mathrm{d}$ in the optic nerve to $1 \mathrm{~mm} / \mathrm{d}$ in the sciatic nerve. The polypeptide composition of $\mathrm{SCb}$ is much more complex and carries more than 200 proteins, including actin (Black and Lasek, 1979), clathrin (Garner and Lasek, 1981), calmodulin (Brady et al., 1981), and brain spectrin (Levine and Willard, 1981), at a rate of $2-4 \mathrm{~mm} / \mathrm{d}$. During both development and regeneration, changes in axonal diameter have been shown to be associated with modulations in cytoskeletal protein synthesis and axonal transport. As one example, Hoffman et al. (1985a, b, 1988) demonstrated the close coupling of reductions in the synthesis and axonal transport of neurofilament proteins to subsequent reductions in axonal caliber.

Since modifications in slow axonal transport of cytoskeleton protein can affect axonal diameter, it was plausible to suggest that Schwann cells might influence axonal morphology, in particular axonal caliber, by modifying the properties of slow axonal transport. The results presented here demonstrate that slow axonal transport in the Trembler mouse differs quantitatively and qualitatively from that in the normal mouse. Both SCa and SCb rates of axonal transport are altered in the presence of the myelin-deficient Schwann cells of the Trembler mouse, even though fast axonal transport is apparently not modified (Boegman et al., 1977). Presumably, alteration of specific intercellular interactions between axons and Schwann cells in the Trembler modifies the transfer of information between the 2 cells, which in turn affects axonal transport of the cytoskeleton. The significance of these differences in axonal transport between Trembler and control will be addressed first for SCa proteins (tubulin and neurofilament proteins) and then for $\mathrm{SCb}$ marker proteins.

In Trembler nerves, transport of neurofilament proteins and tubulin is altered differentially. Transport of neurofilament proteins is significantly slowed, while, in contrast, the mean rate of tubulin transport appears to be increased. In control sciatic nerves, the transport of tubulin is normally distributed between both major components of slow axonal transport. The majority of tubulin moves down the axon with $\mathrm{SCa}$, while a smaller fraction forms a leading front that moves with $\mathrm{SCb}$ proteins (Black and Lasek, 1980; Brady and Lasek, 1982; Lasek and Brady, 1982; Tashiro et al., 1984). In Trembler nerves, a greater proportion of the tubulin is transported at $\mathrm{SCb}$ rates than in control nerves. This redistribution of tubulin between the 2 components of axonal transport in the Trembler can be demonstrated by both qualitative and quantitative approaches, and such analyses reveal a $40 \%$ increase in the relative amount of labeled tubulin transported with $\mathrm{SCb}$ (see Fig. 3).

Increase in the amount of SCb tubulin is a phenomenon that has been previously reported in axons during development and regeneration (Hoffman and Lasek, 1980). In these situations, the total amount of tubulin transported down the axon is increased by regulation of its synthesis, although a redistribution of previously synthesized tubulin between rate components has been reported in the axonal sprouts following regeneration (McQuarrie and Lasek, 1989). Accompanying the increase seen in tubulin synthesis during regeneration is a concomitant decrease in neurofilament synthesis and transport (Hoffman et al., 1985a), although rates of transport are not so clearly affected in this case. The situation appears to be similar, but not identical, in the Trembler. Changes in tubulin transport in the Trembler are similar to those seen in regeneration, but changes in neurofilament transport do not match the changes observed during development or regeneration. There is a clear decrease in the rate of transport for neurofilament proteins (Fig. 5), but no significant changes have been found in the amount present in the axons (data not shown). These differences in tubulin and neurofilament transport suggest that the Trembler mouse nerve parallels in some respects the situation found in a developing or regenerating nerve and differs in other respects. One possibility is that due to the absence or modification of a signal from the Trembler Schwann cells, neurons and axons fail to mature, producing the changes noted in rate of synthesis and/or transport for cytoskeletal proteins.

Transport of SCb proteins is also affected in the Trembler mouse. Velocities for the majority of proteins transported as part of $\mathrm{SCb}$ were slower and more variable in the Trembler. Perhaps the most obvious example was SCb spectrin, which was transported significantly slower than any other SCb protein studied in the Trembler (see Fig. 7). Spectrin interacts with actin as part of the structure of the cortical cytoskeleton, but, like tubulin, is transported with SCa as well as SCb (Levine and Willard, 1981). The mean rate of transport for spectrin could be slowed down as a result of its interaction with other cytoskeletal elements which are also slowed in Trembler, i.e, the neurofilaments. Rates of transport for actin and calmodulin were also slowed, but to a lesser extent than spectrin (see Fig. 6). However, not all $\mathrm{SCb}$ proteins appear to be significantly affected. For example, the rate of transport for clathrin, which typically moves with the fastest $\mathrm{SCb}$ polypeptides, was not significantly different in Trembler and control mice (see Fig. 7).

Two mechanisms might be invoked to explain these results. One possibility would be modification of a signal that acts at the level of the cell body by genomic regulation, such as that already proposed in the case of neurofilament and tubulin changes during regeneration (Wong and Oblinger, 1987; Hoffman et al., 1988). Another possibility would be a modulation of local controls for transport, assembly/disassembly, or organization of the cytoskeletal network (i.e., changes in packing density due to modification of phosphorylation levels, control of a $\mathrm{Ca}^{2+}-$ regulated protease, etc.). For example, fluxes of cytoskeletal eleInents could be affected by changing rates. A faster rate of transport for tubulin would reduce contributions to axonal caliber by increasing the flux of tubulin through the axon. Such a model is consistent with both the altered kinetics of axonal transport and the smaller average axonal caliber seen in the Trembler. Alternatively, the smaller axonal caliber in the Trembler could be due to a denser packing of the cytoskeletal structures. Changes in organization need not involve a change in the total amount of neurofilaments or microtubules present in the axon. Preliminary ultrastructural analyses of the cytoskeleton have shown that there is indeed an increase in the neurofilament density in the Trembler axons (unpublished data and see Low, 1976b). Changes of the latter type are typically seen at the level of the node of Ranvier in peripheral nerves. In the case of Trembler, $\mathrm{SCa}$ and $\mathrm{SCb}$ appear to be affected in a similar fashion, perhaps because the mechanisms responsible for the movement or regulation of that movement are similar. These various mechanisms are not mutually exclusive. At this point, we are unable to distinguish between effects acting at the perikaryal and local levels in the Trembler. The local modifications observed in sciatic nerve grafts from Trembler into normal or normal into Trembler tend to argue in favor of the local control hypothesis, 
but these 2 modes of action could both be involved. Thus, a combination of changes in the genomic regulation and local control appears to be the most plausible hypothesis.

At early stages of neural development, a small number of neurofilaments are transported down the axon at a rate close to $\mathrm{SCb}$. As the nerve matures, there is an increase in neurofilament synthesis coupled with a reduction in the velocity of neurofilament transport and correlated with the enlargement of axonal caliber (Hoffman et al., 1985b). A similar set of phenomena recurs during nerve regeneration after crush or cut injury. Nerve section is followed by a reorganization of the neuron at the level of the cell body including a decrease of neurofilament synthesis (Hoffman et al., 1985a). This reduction in synthesis correlates with the observed decrease in axonal caliber proximal to the lesion. In these 2 cases, caliber correlates well with the degree of neurofilament synthesis. Two important types of information result from these experiments: (1) variations in axonal caliber are directly proportional to changes in neurofilament synthesis, and (2) local, transient fluctuations in neurofilament transport velocity can produce changes inversely proportional to axonal diameter. According to the hypothesis generated from such studies (Hoffman et al., 1985b), reductions in the rate of neurofilament transport such as those seen in Trembler nerves should produce an increase in axonal diameter. However, this model presumes a progressive decrease in the rate of transport of neurofilaments as they move distally, which would indeed result in a local accumulation of neurofilaments and a consequent increase in axonal diameter. Hoffman et al. (1985b) have presented evidence that such progressive reductions in velocity do occur in vivo. However, an overall reduction in velocity all along the axon, such as that which appears to be occurring in Trembler nerves, would not necessarily result in an increased axonal diameter. The reduced average axonal caliber noted in Trembler axons despite a reduction in velocity of slow transport is presumably explained by the increase in neurofilament packing density observed in the Trembler (data not shown).

Given the connections noted above between properties of slow axonal transport and those of development and regeneration, we evaluated the regenerative response in Trembler sciatic nerve. Decreases in the rate of $\mathrm{SCb}$ in the Trembler can indeed be correlated with the decreases in the rate of regeneration in the Trembler. Trembler sciatic nerve motor axons regenerated at a rate of $15-25 \%$ slower than in the control. The decrease in elongation rate, as measured by ${ }^{3} \mathrm{H}$-fucose incorporation into the growing tips, correlated well with the decrease $(16-21 \%)$ in the rate of $\mathrm{SCb}$ in the Trembler. However, elongation of fibers begins in Trembler after an initial delay that is $35-43 \%$ shorter than in a normal mouse.

Changes in delay time as well as in rates of regeneration have been described in other experimental models of regeneration. When a conditioning lesion is administered to a normal nerve before the test lesion, regeneration starts after a much shorter delay, but it then proceeds at a faster rate (McQuarrie, 1978, 1984; Forman et al., 1980; McQuarrie and Grafstein, 1981), unlike Trembler regeneration. The rationale for a reduced delay before regeneration has been attributed to a reorganization in the neuron induced by the conditioning lesion and the resulting alterations in signals moving retrogradely toward the cell body. The net result of a conditioning lesion is to put the nerve into a "regeneration" mode. Nerve function is redirected toward elongation and formation of new axons. This reorganization of the neuronal protein synthesis persists for as long as a few weeks.
There are corresponding increases in the rate of $\mathrm{SCb}$ and increases in the amount of tubulin in $\mathrm{SCb}$. As a result, when the nerve is subjected to a second lesion during that period, there is no need to go through the reorganization process again and regeneration can start without further delay.

The shortened regeneration delays seen in the Trembler imply that Trembler nerves never attain a state of full maturity, so that the machinery for nerve elongation is always ready to be used without delay; i.e., Trembler nerves are perpetually in a "regeneration" mode. Both the increased amount of tubulin in $\mathrm{SCb}$ and the shortened delay before regeneration are consistent with this view. However, the slower rate of elongation in regeneration, which correlates with the slower $\mathrm{SCb}$ rate seen in Trembler, suggests that the factors which control rates of slow transport in the axon are not primed to the same extent in Trembler as in the conditioning lesion paradigm. The differences in the regeneration rate between the normal and the Trembler do correspond to the differences in the rate of $\mathrm{SCb}$ between the normal and the Trembler (see Tables 2 and 3). The functional separation of these 2 parameters raises the possibility of distinct regulatory mechanisms that might be subject to independent modulation by experimental manipulations.

Although the genetic lesion appears to be associated with the Schwann cell rather than the neuron, both slow axonal transport and regeneration are altered in the Trembler. Our results suggest that Schwann cells can modify fundamental properties of the neuron by local control at the level of the axon and possibly also by control at the level of the cell body. The quantitative and qualitative changes in slow axonal transport that are mediated by the myelinating Schwann cells lead, in turn, to modifications of key morphological and physiological properties of the neuron, including axonal caliber and plasticity in the form of regeneration. Our observations suggest that the Schwann cell capacity to interact with axons is more profound than previously recognized and this cell-cell interaction plays an important role in regulating axonal shape and function. A deeper understanding of the intercellular transmission of information between Schwann cell and axon will be essential for our understanding of the mechanisms underlying many neurological disorders as well as for an understanding of the basic mechanisms of neuronal development and regeneration. Parallel studies in the CNS using the Shiverer mutant and a Shiverer transgenic model (de Waegh and Brady, 1988) have already demonstrated that the influence of myelination on the neuron extends to the CNS as well. The interaction between neurons and glial cells in general, and the myelinating process in particular, represents a complex symbiosis that affects many physiologically important aspects of the nervous system.

\section{References}

Aguayo A, Attiwell M, Trecarten J, Perkins S, Bray G (1977) Abnormal myelination in transplanted Trembler mouse Schwann cells. Nature 265:73-74.

Aguayo A, David S, Bray G (1981) Influence of the glial environment on the elongation of axons after injury: transplantation studies in adult rodents. J Exp Biol 95:231-240.

Ayers M, Anderson R (1975) Onion bulb neuropathy in the Trembler mouse: comparison with normal nerve maturation. Acta Neuropathol (Berl) 32:43-59.

Ayers M, Anderson R (1976) Development of onion bulb neuropathy in the Trembler mouse. Morphometric study. Acta Neuropathol (Berl) 36:137-152.

Benley M, Aguayo A (1982) Extensive elongation of axons from rat brain into peripheral nerve graft. Nature 296:150-152. 
Black M, Lasek R (1979) Axonal transport of actin: slow component $b$ is the principal source of actin for the axon. Brain Res 171:402413.

Black M, Lasek R (1980) Slow component of axonal transport: two cytoskcletal networks. J Ccll Biol 86:616-623.

Boegman J, Aguayo A, Bray G (1977) Axoplasmic transport in (Trembler mouse) nerves with a widespread disorder of myelination. Abstr Am Assn Neuropath, 590-592.

Bourre JM, Boiron F, Boutry JM, Cassagne C, Chanez C, Darriet D, Dothi A, Dumont O, Flexor M, Hauw J, Koenig H, Larrouquere S, Piciotti M, Trouillet V (1984) Biochemical aspect of the Trembler mouse (dysmyelinating mutant of the peripheral nervous system with onion proliferation). In: Neuron diseases (Serratrice G, et al, eds). New York: Raven.

Brady S (1985) Axonal transport methods and applications. In: Neuromethods, general neurochemical techniques (Boulton A, Baker G, eds), pp 419-476. Clifton, NJ: Humana.

Brady S, Lasek R (1982) Slow component of axonal transport: movements, composition and organization. In: Axoplasmic transport (Weiss D, ed), pp 206-217. Berlin: Springer-Verlag.

Brady S, Tytell M, Heriot K, Lasek R (1981) Axonal transport of calmodulin: a physiological approach to identification of long term association between proteins. J Cell Biol 89:607-614

DeCaprio A (1985) Molecular mechanism of diketone neurotoxicity. Chem Biol Interactions 54:257-270.

de Waegh S, Brady S (1988) Altered slow axonal transport in optic nerve of shiverer mutant mice. Soc Neurosci Abstr 14:48.1.

Forman D, McQuarrie I, Labore F, Wood D, Stone L, Braddock C, Fuchs D (1980) Time course of the conditioning lesion effect on axonal regeneration. Brain Res 182:180-185.

Fraher JP (1978) Quantitative studies on the maturation of central and peripheral parts of individual ventral motorneuron axons: I. Myelin sheath and axon caliber. J Anat 126:509-533.

Friede RL, Miyagishi T (1972) Adjustment of the myelin sheath to changes in axonal caliber. Anat Rec 172:1-14.

Friede RL, Samorajski T (1970) Axon caliber related to neurofilaments and microtubules in sciatic nerve fibers of rats and mice. Anat Rec 167:379-388.

Garner J, Lasek R (1981) Clathrin is axonally transported as part of slow component $b$ : the microfilament complex. J Cell Biol 88:172178.

Garner J, Lasek R (1982) Cohesive axonal transport of the slow component b complex of polypeptides. J Neurosci 2:1824-1835.

Griffin J, Anthony D, Fahnestock K, Hoffman P, Graham, D (1984) 3,4 Dimethyl 2,5 hexanedione impairs the axonal transport of neurofilament proteins. J Neurosci 4:1516-1526.

Griffin J, Rosenfeld J, Hoffman P, Gold B, Trapp B (1988) The axonal cytoskeleton influences on nerve fiber form and Schwann cell behavior. In: Intrinsic determinant of neuronal form and function, pp 403439. New York: Liss.

Heape A, Juguelin H, Fabre M, Boiron F, Cassagne C (1986) A quantitative study of peripheral nerve lipid composition during myelinogenesis in normal and Trembler mice. Dev Brain Res 25:181-189.

Hoffman P, Lasek R (1975) The slow component of axonal transport identification of major structural polypeptides of the axon and their generality among mammalian neurons. J Cell Biol 66:351-366.

Hoffman P, Lasek R (1980) Axonal transport of the cytoskeleton in regenerating motor neurons: consistency and changes. Brain Res 202: 317-333.

Hoffman P, Griffin G, Price D (1984) Control of axonal caliber by neurofilament transport. J Cell Biol 99:705-714.

Hoffman P, Thompson G, Griffin J, Price D (1985a) Changes in neurofilament transport coincide temporally with alterations in the caliber of axons in regenerating motor fibers. J Cell Biol 101:1332-1340.

Hoffman P, Griffin J, Gold B. Price D (1985b) Slowing of neurofilament transport and the radial growth of devcloping ncrve fibers. $J$ Neurosci 5:2920-2929.

Hoffman P, Koo E, Muma N, Griffin J, Price D (1988) Role of neurofilaments in the control of axonal caliber in myelinated nerve fibers. In: Intrinsic determinants of neuronal forms and functions (Lasek R, Black M, eds), pp 389-402. New York: Liss.

Komiya Y, Cooper N, Kidman A (1986) The long term effect of a single injection of $\beta, \beta^{\prime}$-iminodipropionitrile on slow axonal transport in the rat. J Biochem 100:1241-1246.
Laemmli UK (1970) Cleavage of structural proteins during the assembly of the head of bacteriophage T4. Nature 227:680-685.

Lasek R, Brady S (1982) The structural hypothesis of axonal transport: two classes of moving elements. In: Axoplasmic transport (Weiss D, ed), pp 397-405. Berlin: Springer-Verlag.

Lasek R, McQuarrie I, Wujek J (1981) The central nervous system regeneration problem: neuron and environment. In: Posttraumatic peripheral nerve regeneration: experimental basis and clinical implication (Gorio A, et al, eds), pp 59-70. New York: Raven.

Lasek, R, Oblinger M, Drake P (1983) Molecular biology of neuronal geometry: expression of neurofilament genes influences axonal diameter. Cold Spring Harbor Symp Quant Biol 18:731-744.

Lasek R, Garner J, Brady S (1984) Axonal transport of the cytoplasmic matrix. J Cell Biol 99:212-221.

Laskey RA, Mills AD (1975) Quantitative film detection of ${ }^{3} \mathrm{H}$ and ${ }^{14} \mathrm{C}$ in polyacrylamide gels by fluorography. Eur J Biochem 563:335341.

Levine J, Willard M (1981) Fodrin: axonally transported polypetides associated with the external periphery of many cells. J Cell Biol 90: 631-643.

Low PA (1976a) Hereditary hypertrophic neuropathy in the Trembler mouse. Part 1. Histological studies: light microscopy. J Neurol Sci $30: 327-341$.

Low PA (1976b) Hereditary hypertrophic neuropathy in the Trembler mouse. Part 2. Histological studies: electron microscopy. J Neurol Sci 30:343-368.

Low PA, McLeod IG (1975) Hereditary demyelination neuropathy in the Trembler mouse. J Neurol Sci 26:565-574.

McQuarrie I (1978) The effect of a conditioning lesion on the regeneration of motor axons. Brain Res 152:597-602.

McQuarrie I (1984) Effect of a conditioning lesion on axonal transport during regeneration: the role of slow transport. Adv Neurochem 6: 185-209.

McQuarrie I, Grafstein B (1981) Effect of a conditioning lesion on optic nerve regeneration in goldfish. Brain Res 216:253-264.

McQuarrie I, Lasek R (1989) Transport of cytoskeletal elements from parent axons into regenerating daughter axons. J Neurosci 9:436-446.

McQuarrie I, Brady S, Lasek R (1986) Diversity in the axonal transport of structural proteins: major differences between optic and spinal axons in the rat. $J$ Neurosci 6:1593-1605.

Monaco S, Autilio-Gambetti L, Zabel D, Gambetti P (1985) Giant axonal neuropathy: acceleration of neurofilament transport in optic axons. Proc Natl Acad Sci USA 82:920-924.

Monaco S, Autilio-Gambetti L, Lasek R, Katz M, Gambetti P (1989) Experimental increase of neurofilament rate: decrease in neurofilament number and in axon diameter. Neuropathology 48(1):26-32.

Oblinger M, Lasek R (1988) Axotomy-induced alterations in the synthesis and transport of neurofilaments and microtubules in dorsal root ganglion cells. J. Neurosci 8:1747-1758.

Oblinger M, Brady S, McQuarrie I, Lasek R (1987) Cytotypic differences in the protein composition of the axonally transported cytoskeleton in mammalian neurons. J Neurosci 7:453-462.

Pannese E, Ledda M, Matsuda S (1988) Nerve fibers with myelinated and unmyelinated portion in dorsal spinal root. J Neurocytol 17:693700.

Parhad I, Clark A, Griffin J (1987) The effect of impairment of slow axonal transport on axonal caliber. In: Axonal transport (Smith R, Bisby M, eds), pp 263-277. New York: Liss.

Perkins CS, Aguayo A, Bray G (1981) Behavior of Schwann cells from Trembler mouse unmyelinated fibers transplanted into myelinated ncrve. Exp Neurol 71:515-526.

Pollard J, McLeod J (1980) Nerve grafts in the Trembler mouse: an electrophysiological and histological study. J Neurol Sci 46:373-383.

Tashiro T, Kurokawa M, Komiya Y (1984) Two populations of axonally transported tubulin differentiated by their interactions with neurofilaments. J Neurochem 43:1220-1225.

White F, Burroni D, Ceccarini C, Matthieu JM, Manetti R, ConstantinoCeccarini E (1986) Trembler mouse Schwann cells in culture: anomalies in the synthesis of lipid and proteins. Brain Res 38:185-92.

Willard M, Simon C (1983) Modulations in neurofilament axonal transport during development of rabbit retinal ganglion cells. Cell 35: $551-559$

Windebank AJ, Wood P, Bunge R, Dyck P (1985) Myelination determines the caliber of dorsal root ganglion neurons in culture. $\mathrm{J}$ Ncurosci 5:1563-1569. 
Wong J, Oblinger M (1987) Changes in neurofilament gene expression occurs after axotomy of dorsal root ganglion neurons: an in situ hybridization study. Metabol Brain Dis 2:291-303.

Wujek J, Lasek R (1983) Corrclation of axonal regeneration and slow component $b$ in two branches of a single axon. J Neurosci 3:243-251.
Wujek J, Lasek R, Gambetti P (1986) The amount of slow axonal transport is proportional to the radial dimensions of the axon. $J$ Neurocytol 15:75-83. 